Ann. Biol. anim. Bioch. Biophys., 1978, 18 (2 B), 493-502.

\title{
Cellular, hormonal and ionic interactions related to induced and spontaneous oocyte maturation
}

\author{
by A. W. SCHUETZ.( $\left.{ }^{1}\right)$, J. G. CLOUD
}

The Johns Hopkins University, School of Hygiene and Public Health, Department of Population Dynamics, 615 North Wolfe Street. Baltimore, Maryland 21205, USA.

Summary. Involvement of cellular, ionic and hormonal interactions in the control of spontaneous and induced nuclear and cytoplasmic maturation of starfish oocytes are discussed and compared. Spontaneous oocyte nuclear maturation occurs when large ovarian follicles are isolated into seawater and this process is sensitive to the calcium and hydrogen ion concentrations in seawater. In the presence of calcium ions induction of spontaneous oocyte maturation is closely associated with loss of follicle cells from the oocyte. In the absence of calcium ions, follicle cells are also lost from the oocyte, however, spontaneous maturation is inhibited and denuded oocytes do not mature following return to normal seawater. Exposure of isolated follicle cells to calcium ions results in the release of meiosis inducing substance into the media. Treatment of isolated follicles with acidic seawater inhibits spontaneous oocyte maturation in the presence of calcium ions but without loss of follicle cells. Effects of low $\mathrm{pH}$ on spontaneous maturation are reversible in the presence but not absence of the follicle cells whereas oocytes exposed to calcium free media or low $\mathrm{pH}$ remain responsive to 1 -methyladenine and undergo maturation. Immature oocytes collected in CaFSW also undergo some aspects of cytoplasmic activation (fertilization membrane elevation, cortical granule discharge) in response to sperm or divalent ionophore (A-23187). This occurs without induction of nuclear maturation. Similar activation responses are obtained when immature oocytes are collected and denuded of follicle cells in acidic seawater and not exposed to CaFSW. Results suggest that oocyte cytoplasmic maturation is not necessarily entirely dependent upon nuclear maturation. Data indicate that spontaneous maturation is mediated through calcium and hydrogen ion sensitive processes in the follicle cells, and that these processes are involved in the release of meiosis inducing substance. The evidence support the hypothesis that somatic follicle cells serve as a common mediator for hormone (RNF) induced and spontaneous maturation. Calcium ions appear to play an important role in the functional maturation of both the follicular somatic cells as well as the oocyte. Similarities between spontaneous oocyte maturation in starfish and mammals are discussed.

\section{Introduction.}

A particularly fascinating aspect of the development of fertilizable oocytes concerns the coordinated process of cell growth and meiosis during which characteristic and periodic changes occur in chromosome structure and function. Following initial stages of oocyte development and growth, meiosis becomes arrested at diplotene of

(1) Send correspondence to : Dr Allen W. Schuetz. 
Prophase I and remains in this state until near the time of ovulation or spawning. With disintegration of the nucleus or germinal vesicle, meiosis is reinitiated. This event is accompanied by other cytoplasmic and cell membrane transformations which result in complete oocyte maturation. Results of experimental studies suggest that the local microenvironment of the oocyte at various stages of its development plays a key role in controlling various aspects of nuclear and cytoplasmic maturation.

This discussion concentrates on the final stages of maturation with particular emphasis on the possible importance of ions, hormones, and somatic-germinal cell interactions in development of the fully mature oocyte. Major attention is given to the following : the mechanisms underlying spontaneous and induced maturation, the mode of hormone action in inducing meiosis, and the relationship between maturation and the onset of fertilizability. Data discussed are primarily those obtained in starfish.

In general, two major and apparently conflicting hypotheses have been formulated concerning the mechanism(s) which interrupts meiotic arrest in starfishoocyles. Most simply these hypotheses center on the question of whether the induction mechanism(s) involved in stimulating oocyle maturation is hormonal or non-hormonal (fig. 1). Experimental evidence for hormonal control of meiosis in starfish is of relatively recent origin. These data indicate that control of oocyte maturation involves two hormones acting sequentially (Chaet and McConnaughy, 1959 ; Schuetz and Biggers, 1967 ; Kanatani and Shirai, 1967). A polypeptide hormone (RNF or GSS) from the radial nerve stimulates the synthesis or release of an ovarian product which acts directly on oocytes to reinitiate meiosis (Reviewed ; Schuetz 1969c, 1975 ; Kanatani 1972, 1975). This ovarian product, purified from Asterias amurensis, has been identified as 1-methyladenine (Kanatani et al., 1969).

Alternatively, considerable evidence, both past and present, suggests that interruption of diplotene arrest is controlled by other than hormonal mechanisms. This hypothesis is based primarily on the fact that release of immature oocytes from the ovary; directly into seawater, results in spontaneous reinitiation of meiosis (fig. 1).
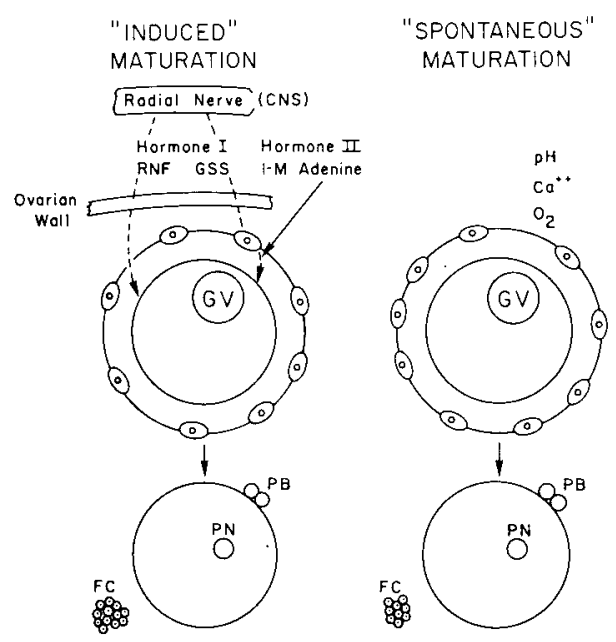

FIG. 1. - Diagram illustrating and contrasting possible factors controlling spontaneous or induced meiotic maturation of starfish ovarian follicles and oocytes. 
On the basis of experiments involving inhibition of spontaneous maturation, a number of factors in seawater, including calcium (Dalcq, 1924), hydrogen and hydroxyl ions, and oxygen content (Loeb, 1902), have been implicated as controlling agents. Thus, in the apparent absence of either of the previously mentioned hormones, the same state of meiotic maturation can be obtained by releasing oocytes into seawater. Mature oocytes obtained by either procedure are capable of undergoing fertilization and embryonic development. Interestingly, much of the data supporting both of these hypotheses has been obtained in the same species, Asterias forbesi.

\section{Spontaneous maturation. General considerations.}

Although spontaneous maturation occurs in many oocytes, it is neither a universally nor uniformly observed phenomenon in starfish. In species including Asterias forbesi, Asterias rubens, Asterias amurensis, and Marthasteriasglacialis, the majority of large oocyles undergo spontaneous maturation when released into seawater during the spawning season. In contrast, the incidence of spontaneous mafuration is very low or absent when similar experiments are conducted using oocytes from Pisaster ochraceus (Schuetz, 1969b), Asterina pectirifera, or Patiria miniata (Hirai and Kanatani, 1971 ; Kanatani, 1975). Furthermore, even within a species such as Asterias forbesi which exhibits a high incidence of spontaneous maturation, there is considerable variation in its frequency. For example, in many cases no spontaneous maturation occurs during the early phase of the breeding season. Additionally, smaller incompletely developed ovarian oocytes typically do not undergo maturation in response to being released from the ovary into seawater or when stimulated with either RNF or 1-methyladenine (Schuetz, 1967). Thus it is quite evident that there are gradations in oocyte responsiveness which are related to processes of oocyte and/or follicular differentiation during oogenesis (Schuetz, 1974).

\section{Cellular-ionic interactions in spontaneous maturation.}

Important for understanding the process of spontaneous maturation is the nature of products released from the torn or mechanically ruptured ovary. Although the oocyte is the cell which undergoes maturation in seawater, it is not the only cell released from the ovary. Within the gonad each immature oocyte is surrounded or encapsulated by a single layer of thin flattened epithelial (follicle) cells (Schuetz and Biggers, 1968). Upon tearing the ovarian wall individual follicular units (immature oocyte and encapsulating follicle cells) are released into the seawater. In general, follicle cells were not considered in earlier studies; however, present evidence suggests that they play an important role in spontaneous maturation.

Dalcq (1924) originally demonstrated that deletion of calcium ions from seawater markedly inhibits spontaneous maturation. From this observation he suggested that calcium ions in seawater play an important and presumably direct role in inducing spontaneous oocyte maturation. Microscopic observation (table 1, Schuetz, unpublished) of spontaneous maturation in calcium containing seawater further indicates a close correlation between disintegration of the germinal vesicle (maturation) and loss 
of follicle cells in Asterias forbesi. Oocytes which remain immature after their release into seawater usually retain their follicle cell envelope for extended periods of time.

TABLE 1

Spontaneous maturation in Asterias forbesi oocyfes : relationship to follicle disintegration

\begin{tabular}{cccccc}
\hline \multirow{2}{*}{ Animal } & $\begin{array}{c}\text { Follicles } \\
\text { examined }\end{array}$ & $\begin{array}{c}\text { Mature oocytes } \\
\text { with F.C. }\end{array}$ & \multicolumn{3}{c}{$\begin{array}{c}\text { Immature oocytes } \\
\text { with F.C. }\end{array}$} \\
\cline { 3 - 7 } & & Total mature & p. 100 & Total immature & p. 100 \\
\hline 1 & 25 & $0 / 3$ & $(0.0)$ & $22 / 22$ & $(100)$ \\
2 & 35 & $0 / 4$ & $(0.0)$ & $28 / 31$ & $(90.3)$ \\
3 & 35 & $0 / 26$ & $(0.0)$ & $8 / 9$ & $(88.9)$ \\
4 & 35 & $1 / 17$ & $(5.9)$ & $13 / 18$ & $(72.2)$ \\
5 & 35 & $1 / 20$ & $(5.0)$ & $15 / 15$ & $(100)$ \\
6 & 35 & $1 / 17$ & $(5.9)$ & $18 / 18$ & $(100)$ \\
7 & 35 & $0 / 1$ & $(0.0)$ & $29 / 34$ & $(85)$ \\
\hline
\end{tabular}

One of the first experimental studies linking calcium ions and follicle cells with meiosis concerned the effects of calcium free seawater (CaFSW treatment on the structure and function of the starfish ovary (Schuetz and Biggers, 1968). Preincubation of ovaries in CaFSW causes disruption and loss of the follicular cell envelope surrounding oocytes within the ovary, relaxation and elongation of the ovary, and inhibition of RNF induced spawning. Interestingly, return of gonads previously exposed to CaFSW back to seawater containing calcium causes a dramatic contraction of the ovarian wall and extrusion of immature oocytes devoid of follicle cells. In many cases such oocytes remain immature in the presence of calcium (Schuetz, unpublished observations; Cloud and Schuetz, 1973). Thus these data suggest that calcium ions do not directly induce meiosis in oocytes ; however, such oocytes do undergo meiosis in response to 1-methyladenine (Cloud and Schuetz, 1973).

Direct evidence for the involvement of the follicle cells in spontaneous maturation of the oocytes has been provided by Cloud and Schuetz (1973) and by Shirai (1974). In these studies it is shown that follicle cells collected and separated in CaFSW from oocytes exhibiting a high degree of spontaneous maturation, release a meiosis inducing substance on exposure to calcium ions. These results have been interpreted to suggest that calcium indirectly induces oocyte maturation through its actions on follicle cells. Follicle cells also appear to play an important role in non-spontaneous maturation induced by RNF (Hirai and Kanatani, 1971) or concanavalin A (Kubota and Kanatani, 1975a, b).

Loeb (1902) obtained reversible inhibition of spontaneous maturation in Asteria forbesi oocytes by altering the $\mathrm{pH}$ of the seawater. This phenomenon has been reinvestigated recently by Cloud and Schuetz (1976). Follicles containing immature oocytes are isolated in acidic seawater. This treatment prevents the loss of follicle cells and inhibits spontaneous oocyte maturation; however, the oocytes remain responsive to 1-methyladenine and mature spontaneously when returned to seawater at normal 
$\mathrm{pH}$ (table 2). Removal of follicle cells in acidic seawater prior to oocytes being returned to normal seawater $(\mathrm{pH} 8)$ prevents spontaneous but not 1-methyladenine induced maturation. Thus the effect of low $\mathrm{pH}$ appears to be mediated through the follicle cells (table 3). These data have been interpreted to suggest that hydrogen ions inhibit the

TABLE 2

Spontaneous maturation of follicles/oocytes os a function of the $\mathrm{pH}$ of seawater

\begin{tabular}{|c|c|c|c|}
\hline Ovarian structure & $\mathrm{pH}$ of seawater & $N$ & $\begin{array}{l}\text { p. } 100 \text { GVBD } \\
\text { (mean } \pm \text { SEM) }\end{array}$ \\
\hline $\begin{array}{c}\text { Follicle } \ldots \ldots \ldots \ldots \\
\text { Follicle } \ldots \ldots \ldots \ldots \\
\text { Oocyte }{ }^{*} \ldots \ldots \ldots \ldots \\
\text { Oocyte }{ }^{*} \ldots \ldots \ldots\end{array}$ & $\begin{array}{l}5 \\
8 \\
5 \\
8\end{array}$ & $\begin{array}{l}3 \\
3 \\
3 \\
3\end{array}$ & $\begin{array}{l}7.3 \pm 1.8 \\
89.7 \pm 3.2 \\
10.3 \pm 1.2 \\
11.7 \pm 0.7\end{array}$ \\
\hline
\end{tabular}

* Oocytes were obtained by mechanically removing the follicle cells in filtered seawater at $\mathrm{pH} 5$.

TABLE 3

The interrelationship of $\mathrm{Ca}^{+2}$ and $\mathrm{pH}$ in the spontaneous maturation of isolated follicles or oocytes

\begin{tabular}{|c|c|c|c|}
\hline $\begin{array}{l}\mathrm{Ca}^{+2} \text { and } \mathrm{pH} \text { of } \\
\text { incubation media }\end{array}$ & Ovarian structure & $N$ & $\begin{array}{l}\text { p. } 100 \text { GVBD } \\
(\text { mean } \pm \text { SEM) }\end{array}$ \\
\hline $\begin{array}{l}9.2 \mathrm{mMCa}^{+2}, \mathrm{pH} 5 \\
0 \mathrm{mMCa}^{+2}, \mathrm{pH} 8 . \\
9.2 \mathrm{mM} \mathrm{Ca}^{+2}, \mathrm{pH} 8\end{array}$ & $\begin{array}{l}\text { Follicle } \\
\text { Oocyte } \\
\text { Follicle } \\
\text { Oocyte } \\
\text { Follicle } \\
\text { Oocyte }\end{array}$ & $\begin{array}{l}4 \\
4 \\
4 \\
4 \\
4 \\
4\end{array}$ & $\begin{array}{r}4.5 \pm 1.5 \\
3.5 \pm 1.5 \\
15.8 \pm 6.2 \\
6.2 \pm 1.6 \\
83.3 \pm 11.5 \\
13.5 \pm 7.2\end{array}$ \\
\hline
\end{tabular}

release of the meiosis-inducing substance from the follicle cells (fig. 2 ) ; possibly by interfering with calcium sensitive processes within the follicle cells. This inhibitory action of hydrogen ions is consistent with observations relating to other calcium dependent secretory process (del Castillo ef al., 1962 ; Landau and Nachshen, 1975).

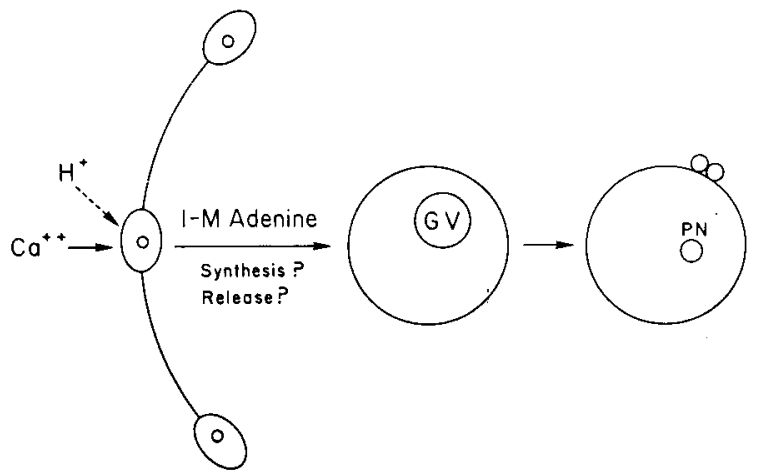

FIG. 2. - Diagram indicating probable locus of action of calcium and hydrogen ions in controlling spontaneous maturation of starfish oocytes. 
Non-ionic factors have also been implicated in the control of spontaneous maturation. Inhibition of spontaneous maturation and follicle cell loss by dinitrophenol was observed by Hull and Schuetz (1970, unpublished observations). Spontaneous maturation has also been inhibited in oocytes of Asterias amurensis using L-phenylalanine at concentrations of $10 \mathrm{mM}$ or greater; the mode of action of L-phenylalanine appears to be via suppression of follicle cell 1-methyladenine production (Shirai, 1974). On the basis of the biological activity of ovarian extracts containing asterosaponins, Ikegami et al. (1976) have suggested that these compounds may act as natural inhibitors of spontaneous and intra-gonadal maturation.

Questions of considerable importance raised by these studies are whether the various treatments which apparently stimulate or inhibit follicle cell production of meiosis inducing substance (1-methyladenine), affect the cellular synthesis and/or release of preformed hormone (Cloud and Schuetz, 1973, 1976 ; Shirai, 1974) or even cause subtle changes in responsiveness of the oocyte. The existence of synthetic and release processes within follicles may in fact form the basis for determining whether oocyte maturation occurs spontaneously or requires additional RNF stimulation. Present data do not allow us to unequivocably distinguish between these alternatives; however, evidence presented and discussed here strongly indicates that spontaneous and induced oocyte maturation are linked by a common cellular and hormonal mechanism, namely somatic cells which are a source of meiosis inducing substance (fig. 1 and 2).

\section{Molecular aspects of meiosis induction.}

Although isolated immature oocytes undergo meiosis in response to 1-methyladenine, the mechanism(s) by which this is accomplished is poorly understood. Hormonal induction of germinal vesicle breakdown does not require the continual presence of the stimulus; thus hormone dependent and hormone independent phases of maturation can be defined (Schuetz, 1969b; Guerrier and Dorée, 1975). As a result of the inability of injected hormone to induce maturation, Kanatani and Hiramoto (1970) conclude that 1-methyladenine has its action at the cell surface. Whether 1 -methyladenine is the active form of the meiosis-inducing substance intracellularly remains unresolved. Toole and Schuetz (1974) obtained chromatographic evidence which shows that immature oocytes incubated with 1-methyladenine contain some product other than 1-methyladenine. They suggest that the conversion may be involved in the induction of maturation. Furthermore, production of the new product is observed only when intact oocytes are utilized, suggesting that the cell membrane is important for its formation. Experiments of Kishimoto and Kanatani (1976) further suggest that cyloplasmic factors are involved in the maturational process. On the basis of competition experiments, Dorée and Guerrier (1975), Dorée, Guerrier and Leonard (1976) conclude that hormone receptors exist on the external surface of the oocyte and that oocyte uplake of 1-methyladenine can be prevented without inhibiting maturation. Our preliminary data indicate, however, that uptake of 1-methyladenine by oocytes may be related to induction of maturation. Treatment of immature oocytes with the local anesthetic procaine inhibits 1-methyladenine induced maturation as well as uptake of the purine (Cloud and Schuetz, 1977). 


\section{Relationship between maturation and fertilization.}

Preparation of the oocyte for fertilization is clearly an important aspect of its differentiation, but the precise time when this occurs has not been well defined. In starfish, it has generally been considered that fertilizability of the oocyte is attained subsequent to germinal vesicle breakdown ; however, recent experiments on germinal vesicle stage oocytes question this idea. Immature Asterias forbesi oocytes, prepared in CaFSW, are treated with the calcium ionophore A-23187 or fertilized with starfish sperm. Under these conditions varying degrees of vitelline membrane separation, fertilization membrane elevation, and cortical granule discharge are obtained (Schuetz, 1975). Cayer et al. (1975) obtained activation of immature Asterina pectinifera following mechanical removal of follicle cells or CaFSW treatment. Lee et al. (1975) also reported fertilization membrane elevation in immature Pisaster giganteus oocytes which lost their follicle cells after being maintained and washed in seawater.

Because of the necessity to wash oocytes in CaFSW to obtain immature follicle cell free germ cells, the possibility arises that CaFSW sensitizes the oocyte to an activating stimulus. To further examine this question, immature oocytes were collected in acidic seawater in order to prevent spontaneous maturation. Follicle cells were removed by mechanical agitation at $\mathrm{pH} 5$ and isolated oocytes were then transferred to normal seawater, treated with calcium ionophore $(A-23187)(4 \mu \mathrm{g} / \mathrm{ml})$ or fertilized with starfish sperm, and examined for activation. Results presented in table 4 show clearly that activation of immature oocytes occurs in response to both A-23187 and sperm even though gametes are never exposed to CaFSW. Furthermore, such oocytes exhibit maturation following the addition of 1-methyladenine. These data suggest that the ability of the oocyte to undergo activation does not necessarily occur subsequent to germinal vesicle breakdown but rather at some stage during the course of oogenesis.

\section{TABLE 4}

Activation of immature starfish oocytes isolated in normal seawater by ionophore (A -23187) and sperm

\begin{tabular}{ccccr}
\hline Treatment & N & $\begin{array}{c}\text { Oocytes * } \\
\text { examined }\end{array}$ & $\begin{array}{c}\text { Immative } \\
\text { oocytes }\end{array}$ & $\begin{array}{c}\text { Oocytes ** } \\
\text { activated }\end{array}$ \\
\hline Ionophore . & 2 & 200 & 184 & 193 \\
DMSO .... & 2 & 200 & 187 & 0 \\
Sperm ..... & 2 & 200 & 187 & 192 \\
Control .... & 2 & 200 & 187 & 0 \\
\hline
\end{tabular}

* Oocytes obtained from 2 animals (100 oocytes/treatment/animal).

** Vifelline membrane elevation.

Analyses of spontaneous maturation in starfish indicate a close coupling of ionicsomatic cell-germinal cell interactions during the process of meiotic maturation. These interactions may occur in other types of organisms as well since similarities between 
spontaneous maturation observed in starfish and in other species, including mammals, are most striking. Pincus and Enzmann (1935), using unmated rabbits, showed that oocytes isolated with their surrounding follicle (cumulus) cells, resumed meiosis spontaneously in vitro. This phenomenon has been seen subsequently in numerous other mammalian species (Edwards, 1962 ; Schuetz, 1974). Recent studies in mice (Schuetz and Swartz, 1974) further indicate a strong correlation between reinitiation of meiosis in oocytes and the morphological condition of the cumulus cells when these cells are examined in the late preoculatory or postovulatory period following ovarian stimulation with exogenous gonadotrophin. Some evidence also suggests that inhibitory substances within the follicle may be involved in the control of meiosis reinitiation (Chang, 1955 ; Tsafriri and Channing, 1975, 1976).

Most importantly, it is not clear whether some or all mechanisms involved in initiating spontaneous maturation experimentally are identical to those which occur under normal conditions. For example, although calcium appears to cause the release of meiosis inducing material by exerting a direct effect on starfish follicle cells in vitro, its physiological role or that of other postulated stimulatory or inhibitory factors within the gonads, in relation to meiosis has not been elucidated fully. Likewise, in mammals, there is little evidence to suggest that alterations in the concentration of elements (sodium, potassium or calcium) within the follicular fluid are associated with follicle and oocyte differentiation (Schuetz and Anisowicz, 1974). Furthermore, calcium ions also play important roles in various functions of the starfish oocyte itself, some of which may be related to the meiotic maturation process (Schuetz, 1975 ; Shen and Steinhardt, 1976 ; Hagiwara et al. 1975 ; Guerrier and Moreau, 1978).

\footnotetext{
$27^{e}$ Congrès international des Sciences physiologiques, Symposium "Germ and somatic cell interaction " Poris, 21-23 juillet 1977.
}

Acknowledgments. - Research discussed was supported in part by grants from the Natural Science Foundation, (BMS 740 4182), NIH 5-T01-HD-0026-11, 1 PO1-HD 05594-02, 5 F 22 HD 0140 7-02. This article was written while Allen W. Schuetz was a Senior International Fellow of the Fogarty Center and their kind support is gratefully acknowledged.

Résumé. L'implication d'interactions cellulaires, ioniques et hormonales dans le contrôle de la maturation nucléaire el cytoplasmique spontanée ou induite des ovocytes d'étoile de mer est discutée. La maturation nucléaire spontanée de l'ovocyte se produit quand les gros follicules ovariens sont isolés dans l'eau de mer. Ce processus est sensible à la concentration en ions calcium et hydrogène de l'eau de mer. En présence d'ions calcium, l'induction de la maturation spontanée de l'ovocyte est étroitement associée au défachement des cellules folliculeuses de l'ovocyte. En l'absence d'ions calcium les cellules folliculeuses se détachent mais la maturation spontanée est inhibée et les ovocytes dénudés ne maturent pas quant ils sont replacés dans de l'eau de mer normale. Les cellules folliculeuses isolées, exposées aux ions calcium, libèrent la substance inductrice de la méiose dans le milieu. Le traitement de follicules isolés par de l'eau de mer acidifiée inhibe la maturation spontanée de l'ovocyte en présence d'ions calcium, mais sans détachement des cellules folliculeuses. Les effets d'un pH bas sur la maturation spontanée sont réversibles en présence, mais pas en l'absence, des cellules folliculeuses, tandis que les ovocytes placés dans un milieu sans calcium ou à un pH bas, restent sensibles à la 1-méthyladénine et peuvent 
maturer. Les ovocytes immatures prélevés dans de l'eau de mer sans calcium montrent quelques signes d'activation cytoplasmique (élévation de la membrane de fécondation, décharge des granules corticaux) en présence de spermatozoïdes ou de l'ionophore divalent (A-23187). Ceci se produit sans induction de la maturation nucléaire. Des activations comparables sont obtenues quand les ovocytes immatures sont dénudés de leurs cellules folliculeuses dans de l'eau de mer acidifiée. Ces résultats suggèrent que :

- la maturation cytoplasmique de l'ovocyte n'est pas nécessairement entièrement dépendante de la maturation nucléaire ;

- des processus sensibles aux ions calcium et hydrogène dans les cellules folliculeuses sont les médiateurs de la maturation spontanée;

- ces processus sont impliqués dans la libération de la substance inductrice de la méiose. Les cellules folliculeuses somatiques serviraient de médiateur commun pour la maturation spontanée ou induite par l'hormone (RNF). Les ions calcium semblent jover un rôle important dans la maturation fonctionnelle aussi bien des cellules folliculeuses que de l'ovocyte. Les similitudes entre la maturation spontanée de l'ovocyte. de l'étoile de mer et celle des mammifères sont discutées.

\section{References}

CASTILLO J. del, NELSON T. E., SANCHEZ V., 1962. Mechanism of the increased acetylcholine sensitivity of skeletal muscle in low pH solution. J. cell. comp. Physiol., 59, 35-44.

CAYER M. L., KISHIMOTO T., KANATANI H., 1975. Formation of the fertilization membrane by insemination of immature starfish oocytes pretreated with calcium free seawater. Develop. Growth and Different., 17, 119-125.

CHAET A. B., McCONNAUGHY R., 1959. Physiological activity of nerve extracts, Biol. Bull., $117,407$.

CHANG M. C., 1955. The maturation of rabbit oocytes in culture and their maturation, activation and fertilization and subsequent development in the fallopian tubes. J. exp. Zool., 128, 379-405.

CLOUD J. G., SCHUETZ A. W., 1973. Spontaneous maturation of starfish oocytes. Role of calcium ions and follicle cells. Exp. Cell Res., 79, 446-450.

CLOUD J. G., SCHUETZ A. W., 1976. A reversible hydrogen ion blockade of spontaneous oocyte maturation in the starfish : locus of action. J. exp. Zool., 197, 357-362.

CLOUD J. G., SCHUETZ A. W., 1977. Procaine inhibition of 1-methyl-adenine-induced maturation in starfish oocytes. 10 th Annu. Meet. Soc. for the Study of Reproduction.

DALCQ A., 1924. Recherches expérimentales et cytologiques sur la maturation ef l'activation de l'œuf d'Asteria glacialis. Arch. Biol., 34, 507-674.

DORÉE M., GUERRIER P., 1975. Site of action of 1-methyladenine in inducing oocyte maturation in starfish. Exp. Cell Res., 9, 296-300.

DORÉE M., GUERRIER P., LEONARD N. J., 1976. Hormonal control of meiosis : specificity of the 1-methyladenine receptors in starfish oocytes. Proc. nat. Acad. Sci. U. S. A., 73, 1669-1673.

EDWARDS R. G., 1962. Meiosis in ovarian oocytes of adult mammals. Nature, 196, 446-450.

GUERRIER P., DORÉE M., 1975. Hormonal control of reinitiation of meiosis in starfish : the requirement of 1-methyladenine during nuclear maturation. Develop. Biol., 47, 341-348.

GUERRIER P., MOREAU M., DORÉE M., 1978. Control of meiosis reinitiation in starfish : calcium ion as the primary effective trigger. Ann. Biol. anim. Bioch. Biophys., 18, 441-452.

HAGIWARA S., OZAWA S., SAND O., 1975. Voltage clamp analysis of two inward current mechanisms in the egg membrane of a starfisch. J. gen. Physiol., 65, 617-644.

HIRAI S., KANATANI H., 1971. Site of production of meiosis-inducing substance in ovary of starfish. Exp. Cell Res., 67, 224-227.

IKEGAMI S., KAMIYA Y., SHIRAI H., 1976. Characterization and action of meiotic maturation inhibitors in starfish ovary. Exp. Cell Res., 103, 233-239.

KANATANI H., 1972. Adenine derivatives and oocyte maturation in starfishes, 459-478. In BIGGERS J. D., SCHUETZ A. W., Oogenesis, Univ. Park Press, Baltimore, USA. 
KANATANI H., 1975. Mafuration-inducing substances in asteroid and echinoid oocytes. Amer. Zool., 15, 493-505.

KANATANI H., HIRAMOTO Y., 1970. Site of action of 1-methyladenine in inducing oocyte maturation in starfish. Exp. Cell. Res., 61, 280.

KANATANI H., SHIRAI H., 1967. In vitro production of meiosis-inducing substance by nerve extract in ovary of starfisch. Nature (London), 216, 284-286.

KANATANI H., SHIRAI H., NAKANISHI K., KUROKAWA T., 1969. Isolation and identification of meiosis inducing substance in starfish Asterias amurensis. Nature (London), 221, 273-275.

KISHIMOTO T., CAYER M. L., KANATANI H., 1976. Starfish oocyte maturation and reduction of disulfide-bonds on oocyte surface. Exp. Cell Res., 101, 104-110.

KISHIMOTO T., KANATANI H., 1976. Cytoplasmic factor responsible for germinal vesicle breakdown and meiotic maturation in starfish oocyte. Noture, 260, 321-322.

KUBOTA J., KANATANI H., 1975a. Conconavalin A : its action in inducing oocyte maturationinducing substance in starfish follicle cells. Science, 187, 654-655.

KUBOTA J., KANATANI H., 1975b. Production of 1-methyladenine induced by conconavalin $A$ in starfish follicle cells. Develop. Growth and Different., 17, 177-185.

LANDEAU E. M., NACHSHEN D. A., 1975. The interaction of $\mathrm{pH}$ and divalent cations at the neuromuscular junction. J. Physiol., 251, 775-790.

LEE H. H., GOLL E., PLENZLER M., 1975. Membrane reactions during ferfilization and 1-methyladenine stimulation in immature starfish oocytes. Develop. Growth and Different., 17, 335-341.

LOEB J., 1902. Maturation, natural death and the prolongation of the life of the unfertilized starfish eggs (Asterias forbesi) and their significance for the theory of fertilization. Biol. Bull. 3, 295 311.

PINCUS G., ENZMANN E. V., 1935. The comparative behavior of mammalian eggs in vivo and in vitro. I. The activation of ovarian eggs. J. exp. Med., 62, 665-678.

SCHUETZ A. W., 1967. Variable sensitivity of starfish ovarian tissue to radial nerve factor. Exp. Cell Res., 48, 183-186.

SCHUETZ A. W., 1969a. Chemical properties and physiological actions of a starfish. Radial nerve factor and ovarian factor. Gen. comp. Endocrinol., 12, 209-221.

SCHUETZ A. W., 1969b. Induction of oocyte shedding and meiotic maturation in Pisaster ochraceus : kinetic aspects of radial nerve factor and ovarian factor induced changes. Biol. Bull., 137, 524534.

SCHUETZ A. W., 1969c. Oogenesis process and their regulation. In Recent Advances in Reproduction Physiology, Vol. 4, 100-148.

SCHUETZ A. W., 1974. Role of hormones in oocytes maturation. Biol. Reprod., 10, 150-178.

SCHUETZ A. W., 1975. Cytoplasmic activation of starfish oocytes by sperm and divalent ionophore (A-23187). J. Cell Biol., 66, 86-94.

SCHUETZ A. W., ANISOWICZ A., 1974. Ionic and protein composition of ovarian follicular fluid of the pig. Biol. Reprod., 11, 64-72.

SCHUETZ A. W., BIGGERS J. D., 1967. Regulation of germinal vesicle breakdown in starfish oocytes. Exp. Cell Res., 46, 624-628.

SCHUETZ A. W., BIGGERS J. D., 1968. Effect of calcium in the structure and functional response of the starfish ovary to radial nerve factor. J. exp. Zool., 168, 1-10.

SCHUETZ A. W., SWARTZ W., 1974. Asynchromy of ovulation and oocyte maturation in gonadotropin stimulated adult mice. SSR Absir.

SHEN S., STEINHARDT V. N., 1976. An electrophysiological study of the membrane properties of the immature and mature oocyte of the batstar, Patiria miniata. Develop. Biol., 48, 148-162.

SHIRAI H., 1974. Effect of L-phenylalanine on 1-methyladenine production and spontaneous oocyte maturation in starfish. Exp. Cell Res., 87, 31-38.

TOOLE B. P., SCHUETZ A. W., 1974. Evidence for metabolism of 1-methyladenine during induction of starfish oocyte maturation in vitro. Develop. Biol., 39, 177-182.

TSAFRIRI A., CHANNING C. P., 1975. An inhibitory influence of granulosa cells and follicular fluid upon porcine oocyte meiosis in vitro. Endocrinology, 96, 922-927.

TSAFRIRI A., POMERANTZ S. H., CHANNING C. P., 1976. Inhibition of oocyte maturation by porcine follicular fluid : partial characterization of the inhibitor. Biol. Reprod., 14, 511-516. 